\title{
The Panel Study of Income Dynamics: overview, recent innovations, and potential for life course research
}

\author{
Katherine A McGonagle \\ Institute for Social Research, University of Michigan \\ kmcgon@umich.edu
}

Robert F Schoeni

Institute for Social Research, Department of Economics and Gerald R. Ford School of Public Policy, University of Michigan Narayan Sastry

Institute for Social Research, University of Michigan

Vicki A Freedman

Institute for Social Research, University of Michigan

\section{Abstract}

Spanning over four decades, the Panel Study of Income Dynamics (PSID) is the world's longestrunning household panel survey. The resulting data archive presents research opportunities for breakthroughs in understanding the connections between economic status, health and wellbeing across generations and over the life course. The long panel, genealogical design, and broad content of the data represent an unique opportunity for a multi-perspective study of life course evolution and change within families over multiple generations. Based on relational data structures and advanced web-based archiving and delivery tools, the PSID has a publicly available web-based facility for users worldwide to create customized data extracts and codebooks, based on nearly 70,000 variables from over 70,000 individuals over 44 years. This paper provides an overview of the PSID and its supplemental studies, the Disability and Use of Time Supplement, the Child Development Supplement, and the Transition into Adulthood study, and describes features and recent enhancements that have increased the potential of the archive for studying life course development.

Keywords: panel study, life course, data collection, human development, time use, young adulthood, aging

\section{Introduction}

The world's longest-running household panel survey was originally created in the United States of America to assess President Lyndon Johnson's 'War on Poverty'. In 1966 and 1967, the Office of Economic Opportunity (OEO) directed the U.S. Bureau of the Census to design and field the Survey of Economic Opportunity (SEO) to provide data for a national assessment of War on Poverty programs. A representative national sample of approximately 22,000 households and an over sample, in census enumeration districts with large non-white populations, of approximately 15,000 households was drawn by the Census Bureau and interviews were completed with 30,000 of these households. Interest in continuing the study with the primary goal of understanding the dynamics of economic well-being led the OEO to approach the Survey Research Center (SRC) at the University of Michigan about continuing to interview a sub-sample of low-income SEO households. Professor James N. Morgan, who eventually became the study's first director at Michigan, argued successfully for adding a crosssection of households from the SRC national sampling frame so that the study would also include non-poor 
households and hence represent the entire population of the U.S. In addition, a fortuitous decision was made to follow family members who moved out of study households, such as children who came of age during the study. This allowed the sample to remain representative of the nation's families and individuals over time. This study became what is now called the Panel Study of Income Dynamics (PSID; Hill, 1992).

Launched in 1968, PSID will soon mark its $44^{\text {th }}$ anniversary. The data are a cornerstone of social science research in the U.S.: more than 3,200 peer-reviewed publications are based on the PSID, nine U.S. federal agencies utilize the data in fulfilling their missions, annually nearly 25,000 data extracts are downloaded by over 2,500 different users world-wide, and there are nearly 5 million visits to the PSID website each year. As an indicator of its significance, the study's lead sponsor, the U.S. National Science Foundation (NSF), named PSID as one of the 60 most important innovations that NSF played a key role in creating.

Starting in the late 1990s, several developments increased the potential of the PSID archive for studying life course development. Most notably, content was expanded in the areas of health, wealth, expenditures, philanthropy, child development, the transition to adulthood, and time use. This paper provides a detailed profile of PSID and recent supplemental studies, highlighting the features that enhance the value for longitudinal and life course research. The sections below describe the design and content of the PSID main interview, the Disability and Use of Time Supplement, the Child Development Supplement, and the Transition into Adulthood study, the distribution of data and documentation, funding and administration, the analytic potential for life course research, including research examples designed to stimulate new ideas and discoveries, and what the future holds for PSID.

\section{The PSID Main Interview}

The primary source of information on PSID sample members has been a survey conducted annually through 1997 and biennially thereafter. This survey, called the "main interview," is described in this section. Subsequent sections describe supplemental data collections on PSID sample members.

\subsection{Study design and following rules}

The original aim of studying the dynamics of income and poverty led the 1968 sample to be formed from an oversample of 1,872 low income families from the SEO and a nationally representative sample of 2,930 households designed by the SRC. Approximately 18,000 individuals lived in these original families at that time, and are considered to have the "PSID gene" making them eligible to be followed for subsequent interviews. In addition, all individuals born to or adopted by an individual with the PSID gene acquire the gene themselves, becoming PSID "sample persons" who are followed in the study. As members of sample families grow up, move out, and form their own economically independent households, they are interviewed separately, increasing the overall number of interviews conducted each wave. ${ }^{\text {ii }}$

This unique design of following children of sample members as they themselves become adults, replenishes the sample and helps to maintain its national representation, as well as facilitating the study of outcomes across generations.

In 1990, 2,043 Latino households, including families originally from Mexico, Puerto Rico, and Cuba, were added to the study. While this sample represented three major groups of immigrants, it did not include all post-1968 immigrants. Because of this crucial shortcoming, and a lack of sufficient funding, the Latino sample was dropped after 1995.

In 1997, because of the escalation in costs driven by the doubling of the sample size during its 30-year history, PSID was forced to drop some families from the SEO oversample. At the same time, a sample of 511 families who had immigrated to the U.S. after 1968 was added, in order to maintain the national representation of U.S. families in the study. iii Budget constraints limited the size of the addition, preventing it from being large enough to support the analysis of immigrant subgroups. Because some of these families created split-off families, their overall number increased to 638 by 2009 .

\subsection{Respondents and sample sizes}

The definitions and terminology used to describe the PSID sample were adopted from the Census Bureau in 1968 and, although dated, are maintained for consistency and for their straightforward following 
rules. A single primary adult serves as the respondent. In a married-couple family, the Head is defined as the husband-unless he is physically or mentally incapable of being interviewed. The Head can also be a single female. The term Wife is used for a female in a married couple and "Wife" is used for a cohabitating female (henceforth, the former term is used for both married and cohabiting female partners). PSID attempts to interview the same family member in each wave to maximize consistency over time; approximately $95 \%$ of families that appear in successive waves have the same respondent for both interviews.

PSID respondents provide information about themselves, their spouse/partner, and all other family members living together, who are referred to as the "family unit." Individuals who are not Heads or Wives are classified as "other family unit members" if, at the time of interview, they are members of the respondents' family and either residing in the interviewed family unit or temporarily away in an institution (e.g. college, jail, hospital, or the military). Family members are individuals who are related to the Head/Wife by blood, marriage, or adoption, although unrelated individuals are included if they are permanently living together and share income and expenses.

Table 1 shows that in 2009 the PSID sample was comprised of 8,690 family units consisting of 13,410 Heads/Wives and 23,102 individual family members (including Heads/Wives). There are substantial sample sizes of individuals at all ages: 7,511 at ages 0$18,7,396$ at ages $19-39,5,678$ at ages $40-59$, and 2,517 aged 60 and older. In 2009, 13,041 individuals with the PSID gene had been part of the interviewed sample for at least five waves; 5,876 had survived and participated in every wave since 1968 , providing large samples of individuals who have been observed over a substantial portion of their life course.

Table 1. Numbers of PSID individuals and Heads/Wives in 2009 by age group

\begin{tabular}{ccccr} 
& \multicolumn{2}{c}{ Individuals $^{\mathbf{1}}$} & \multicolumn{2}{c}{ Heads/Wives } \\
Age Group & $\mathbf{N}$ & \% & $\mathbf{N}$ & \% \\
$0-18$ & 7511 & 32.5 & 28 & 0.2 \\
$19-39$ & 7396 & 32.0 & 5700 & 42.5 \\
$40-49$ & 2891 & 12.5 & 2744 & 20.4 \\
$50-59$ & 2787 & 12.1 & 2621 & 19.6 \\
$60-69$ & 1397 & 6.1 & 1287 & 9.6 \\
$70+$ & 1120 & 4.8 & 1030 & 7.7 \\
All ages & 23102 & 100.0 & 13410 & 100.0 \\
& & & &
\end{tabular}

\subsection{Response rates}

The PSID has consistently achieved response rates equal to or higher than other panel surveys worldwide (Schoeni et al forthcoming). Response rates are calculated for each of the "sample types" within PSID. The sample is defined across two different strata: first, whether it is considered "core" versus "immigrant refresher", and second, whether in the previous wave, the sample type is "re-interview" versus "split-off" versus "re-contact." In regards to the first strata, the "core" sample consists of all families except those added in the 1997 immigrant refresher sample. In regards to the second strata, the "re-interview sample" includes families who were successfully interviewed in the previous wave. "Splitoff" families consist of individuals who left a PSID family unit and established their own economically independent unit. Finally, the "re-contact" sample consists of families who did not respond in the previous wave, but were respondents in the wave before the previous wave. PSID attempts to recontact and interview these families in subsequent waves, as a way to minimize attrition and maintain the representativeness of the sample. 
Table 2. Response rate each wave by sample type and interview tṿpe: 1968 to present

\begin{tabular}{|c|c|c|c|c|c|c|c|c|c|c|c|}
\hline \multirow{3}{*}{\begin{tabular}{|l} 
\\
Year \\
\end{tabular}} & & Tante z. ne & epurtise & actis & & & & \\
\hline & & \multicolumn{4}{|c|}{ Core } & & \multicolumn{5}{|c|}{ Latino (1990-95)/ Immigrant (1997-present) } \\
\hline & Total & $\begin{array}{c}\text { Re- } \\
\text { interview }\end{array}$ & Re-contact & $\begin{array}{l}\text { Split- } \\
\text { ct off }\end{array}$ & $\begin{array}{c}\text { Re-contact } \\
\text { split-off } \\
\end{array}$ & Total & $\begin{array}{c}\text { Re- } \\
\text { interview }\end{array}$ & Re-contact & $\begin{array}{l}\text { Split- } \\
t \text { off }\end{array}$ & $\begin{array}{c}\text { Re-contac } \\
\text { split-off } \\
\end{array}$ & Total \\
\hline 1968 & 76.0 & & & & & & & & & & \\
\hline 1969 & 81.4 & 89.0 & & 60.4 & & 81.4 & & & & & \\
\hline 1970 & 95.7 & 97.0 & & 84.0 & & 95.7 & & & & & \\
\hline 1971 & 96.5 & 97.0 & & 86.0 & & 96.5 & & & & & \\
\hline 1972 & 97.8 & 98.5 & & 88.0 & & 97.8 & & & & & \\
\hline 1973 & 97.8 & 98.5 & & 88.9 & & 97.8 & & & & & \\
\hline 1974 & 97.6 & 98.0 & & 92.5 & & 97.6 & & & & & \\
\hline 1975 & 97.8 & 98.4 & & 88.6 & & 97.8 & & & & & \\
\hline 1976 & 97.0 & 98.0 & & 87.0 & & 97.0 & & & & & \\
\hline 1977 & 97.6 & 98.0 & & 90.3 & & 97.6 & & & & & \\
\hline 1978 & 98.0 & 98.3 & & 90.0 & & 98.0 & & & & & \\
\hline 1979 & 97.5 & 98.2 & & 86.5 & & 97.5 & & & & & \\
\hline 1980 & 97.6 & 98.0 & & 90.0 & & 97.6 & & & & & \\
\hline 1981 & 97.7 & 98.3 & & 85.7 & & 97.7 & & & & & \\
\hline 1982 & 98.0 & 98.8 & & 86.0 & & 98.0 & & & & & \\
\hline 1983 & 98.0 & 98.3 & & 88.3 & & 98.0 & & & & & \\
\hline 1984 & 97.7 & 98.0 & & 92.4 & & 97.7 & & & & & \\
\hline 1985 & 97.3 & 97.7 & & 92.0 & & 97.3 & & & & & \\
\hline 1986 & 97.1 & 97.4 & & 89.5 & & 97.1 & & & & & \\
\hline 1987 & 97.2 & 97.8 & & 82.9 & & 97.2 & & & & & \\
\hline 1988 & 97.6 & 98.0 & & 87.2 & & 97.6 & & & & & \\
\hline 1989 & 97.4 & 97.9 & & 83.3 & & 97.4 & & & & & \\
\hline 1990 & 91.7 & 98.3 & & 89.2 & & 98.0 & & & & & 74.8 \\
\hline 1991 & 96.1 & 98.2 & & 86.1 & & 97.8 & 92.3 & & 64.7 & & 90.2 \\
\hline 1992 & 96.0 & 98.0 & & 85.7 & & 97.6 & 92.6 & & 66.7 & & 90.4 \\
\hline 1993 & 92.2 & 95.5 & 52.1 & 67.9 & 47.4 & 94.7 & 87.7 & na & 54.5 & na & 84.5 \\
\hline 1994 & na & 95.9 & na & na & na & na & na & na & na & na & na \\
\hline 1995 & na & 97.0 & na & na & na & na & na & na & na & na & na \\
\hline 1996 & na & 97.6 & na & na & na & na & & & & & \\
\hline 1997 & na & 95.7 & na & na & na & na & & & & & na \\
\hline 1999 & 90.7 & 96.0 & 54.6 & 82.3 & 50.0 & 93.1 & 82.8 & 32.9 & 65.5 & 0.0 & 66.4 \\
\hline 2001 & 91.7 & 96.7 & 52.0 & 79.7 & 0.0 & 93.0 & 88.5 & 31.1 & 61.4 & 0.0 & 76.4 \\
\hline 2003 & 92.7 & 96.6 & 57.6 & 79.6 & 42.9 & 93.4 & 93.9 & 48.9 & 58.1 & 0.0 & 83.9 \\
\hline 2005 & 93.9 & 97.4 & 58.2 & 81.4 & 42.9 & 94.6 & 93.1 & 38.5 & 67.7 & 0.0 & 85.4 \\
\hline 2007 & 93.2 & 96.4 & 46.3 & 85.5 & 71.4 & 93.9 & 92.3 & 31.7 & 73.7 & 66.7 & 85.1 \\
\hline 2009 & 94.3 & 97.0 & 53.5 & 88.7 & 53.8 & 94.7 & 95.5 & 44.4 & 84.6 & 0.0 & 89.8 \\
\hline
\end{tabular}

Notes. na=not available 
Table 2 presents response rates for each wave from 1968 to 2009. The core re-interview sample accounts for roughly $85 \%$ of the entire sample in recent waves and has a wave-to-wave response rate in almost all waves of $95-98 \%$. The core split-off sample experiences response rates typically in the mid-80\% range. The core re-contact sample has response rates in the $50 \%$ range in recent waves, and the core recontact split-off sample is small with variable response rates (e.g. $71 \%$ in $2007,54 \%$ in 2009). The response rates for the 1997 immigrant refresher sample are slightly lower than for the core sample; in 2009 the response rates were $96 \%$ for the immigrant reinterview sample, $85 \%$ for the immigrant split-off sample, and $44 \%$ for the immigrant re-contact sample.

\subsection{Data collection and panel maintenance}

The Survey Research Operations group at the Institute for Social Research has fielded every wave of PSID. Interviews were conducted annually between 1968 and 1997 and biennially thereafter through to the most recent wave in 2011. Since 1973 the majority of interviews in each wave have been conducted via telephone and a computer-assisted telephone collection technology has been used since 1993 (see Couper and Nicholls 1998).

Although most cross-sectional surveys have experienced major declines in response rates over the past several years (de Leeuw and de Heer 2002; Curtin et al 2005; Card et al 2010), response rates in the most recently completed wave were as high as any in the entire history of the PSID. These high rates are attributable to a number of factors, including: incentive payments that translate into roughly $\$ 1$ per average minute of the interview, that are mailed to respondents within a few days of the interview; an additional small incentive for completion of the interview on a cell phone to compensate for use of paid minutes; maintaining experienced interviewers who are repeatedly matched with the same families; tailored refusal conversion techniques; a respondent newsletter highlighting the importance of the study; inter-wave communications with respondents that include a small incentive for providing updated contact information (McGonagle et al 2011). PSID regularly runs methodological experiments to further improve response rates. Results from a recent experiment indicate that sending respondents a small incentive for providing updated contact information between waves reduces field effort and costs (McGonagle et al 2011a, b; McGonagle et al 2009).

\subsection{Sample representativeness}

Despite consistently high response rates, there is evidence that lower income families have higher cumulative attrition (e.g. Fitzgerald et al 1998; Fitzgerald 2011). However, parameter estimates of interest have not been found to be biased. In a recent analysis of the effects of cumulative attrition in PSID up to 2007, Fitzgerald (2011) finds little-to-no evidence of biased estimates of sibling correlations, or of parameters, in inter-generational models of health outcomes. The close alignment of weighted estimates from PSID with those from other U.S. benchmark studies - the March Current Population Survey for income (Gouskova et al 2010), the Survey of Consumer Finances for wealth (Bosworth and Anders 2008), the National Health Interview Survey for health status and health behaviors (Andreski et al 2009), the Consumer Expenditures Survey for expenditures (Li et al 2010), and the American Time Use Survey for time use behaviors (Cornman et al 2011)-support the claim that PSID remains representative of the U.S. population. In other words, cumulative effects of modest wave-to-wave attrition do not appear to have biased the PSID's cross-sectional representation of key economic or health factors. Although families comprised entirely of post-1997 immigrants are not part of the sampling frame, this group is a small segment of the U.S. population and over time joins the PSID sample through intermarriage. Nonetheless, the addition of a post-1997 immigrant refresher sample remains a high priority for the project's strategic plan.

Item non-response is also low, with very few questions missing responses for more than $3-4 \%$ of cases (Killewald et al 2011). Sample weights are provided for each wave to account for differential probabilities of selection due to the original sample design and subsequent attrition, including longitudinal individual weights, longitudinal family weights, and cross-sectional individual weights. Information about the construction of these weights and their analytic use is provided in companion documents on the PSID website.

http://psidonline.isr.umich.edu/Guide/documents.aspx 


\subsection{Content domains}

A central aim of the PSID since its inception has been to collect and distribute detailed information on income and family demographics in order to support research on the dynamics of economic well-being. With input from its Board of Overseers and the broader scientific community, the Study has been expanded over time to collect and distribute data in many domains, to allow the study of topics of emerging scientific and policy interest. Data have been collected on a wide array of social, demographic, economic, and health topics, which have in turn supported unique multidisciplinary research. In 2011, the 89 minute interview collected data on: employment, earnings, income from all sources, expenditures covering $95-100 \%$ of total household spending (Charles et al 2004), housing, foreclosure and mortgage distress, geospatial data, health status, health behaviors, adult and childhood health conditions, health insurance, marriage and fertility, program participation, vehicle ownership, wealth and pensions, debt, and philanthropy. As Table 3 shows, many of these areas have been included in the instrument since 1968. Thousands of additional variables in other domains have been collected throughout the history of the PSID.

Table 3. Content of the PSID 2011 main interview

\begin{tabular}{|l|c|}
\multicolumn{1}{|c|}{ Economic content } & $\begin{array}{c}\text { Year first } \\
\text { collected }\end{array}$ \\
\hline Housing characteristics (foreclosure and mortgage distress), utilities & 1968 (2009) \\
\hline Employment & 1968 \\
\hline Income & 1968 \\
\hline Government transfer program participation & 1968 \\
\hline Consumption expenditures & 1984 \\
\hline Wealth and active savings & 1968 \\
\hline Pensions Health content & 1976 \\
\hline Philanthropic giving and volunteering & 2001 \\
\hline Housework and child care & 1968 \\
\hline & \\
\hline Work and activity limitations & 1968 \\
\hline Health insurance & 1968 \\
\hline Smoking and alcohol & 1968 \\
\hline Workers' compensation & 1977 \\
\hline Hospital and nursing care & 1981 \\
\hline Social security disability insurance & 1984 \\
\hline General health status & 1984 \\
\hline Exercise & 1986 \\
\hline Height and weight & 1986 \\
\hline Activities of daily living / Instrumental activities of daily living & 1992 \\
\hline Health conditions & 1999 \\
\hline Emotional distress & 2001 \\
\hline Overall life satisfaction & 2009 \\
\hline Health expenditures & 1999 \\
\hline General health status in childhood & 1999 \\
\hline Health conditions in childhood & 2007 \\
\hline Medication use & 2011 \\
\hline
\end{tabular}


(Table 3 cont'd)

\begin{tabular}{|l|c|}
\hline \multicolumn{2}{|c|}{ Social and demographic content } \\
\hline Family composition and residential changes & 1968 \\
\hline Deaths & 1968 \\
\hline Marital and birth histories & 1968 \\
\hline Education of head, wife, children, and parents of head and wife & 1968 \\
\hline $\begin{array}{l}\text { Current and first occupation/industry of head, wife (occupation of } \\
\text { parents of head and wife) }\end{array}$ & 1968 \\
\hline \multicolumn{1}{|c|}{ Restricted data available under contract } \\
\hline Geospatial data (tract, block, county where grew up) & 1968 \\
\hline Vehicle model & 1999 \\
\hline Cause and date of death (National Center for Health Statistics) & 1979 \\
\hline Medicare claims (Centers for Medicaid and Medicare Services) & 1991 \\
\hline $\begin{array}{l}\text { Secondary school characteristics (National Center for Education } \\
\text { Statistics) }\end{array}$ & 1968 \\
\hline Housing subsidies (Department of Housing and Urban Development) & 1968 \\
\hline
\end{tabular}

Two modules were recently added that present special opportunities for life course research. Added in 2007, the childhood health calendar was designed to provide data on the reasons for the strong and persistent relationship between health status and socio-economic status and its evolution over the life course. The module includes a series of retrospective questions on whether and when Heads and Wives experienced a set of health conditions during their own childhood, including: asthma, diabetes, respiratory disorders, speech impairment, depression, drug or alcohol problems, and other emotional problems. The collection of these data enhances the power of the PSID to examine the effects of health on life course development, by providing markers very early in the life span. Analyses of these data have demonstrated their validity (Smith 2009).

Starting in 2009, new questions were added about mortgage distress, including foreclosure activity, falling behind in payments, mortgage modifications, and expectations about payment difficulties in the coming year. These data can be used to examine the medium-term effects of the recent economic recession on a range of outcomes, including family formation and dissolution, childbearing, and educational attainment. Researchers can examine, for instance, whether higher unemployment rates and declines in income and wealth have led young adults to postpone or avoid higher education, marriage and cohabitation, and childbearing. The estimation of causal effects is made possible by the repeated measures on respondents, the presence in the data of siblings, cousins, and other related individuals, regional variation in the severity of the recession, and the long and rich historical record on individuals and families.

To maintain respondent confidentiality, some PSID data are available only through restricted use contract to users who follow an appropriate data safeguarding plan, including geospatial identifiers and a variety of linked administrative records. Geospatial identifiers, including Census tract, block-group, and block, are available for the current residence at each wave for all families since 1968 . $^{\text {iv }}$ County-level data on where PSID individuals and their parents grew up are also available. Links to external administrative data sources have been expanded in recent years, with information now available under restricted use contract on: date and cause of death from the National Center for Health Statistics National Death Index for decedents since 1979; health care claims for 1991-2008 from the Centers for Medicare and Medicaid Services; whether the family has received housing subsidies from the Department of Housing and Urban Development; and school characteristics from the National Center for Education Statistics for primary and secondary public and private schools attended by sample members. 


\section{Disability and Use of Time Supplement (DUST)}

Fielded in 2009, the scientific aim of DUST was to produce a rich and nationally focused data archive to support innovative research on disability, time use, and well-being for older married couples (Freedman and Cornman, 2011). A total of 755 PSID Heads and Wives were each interviewed about two randomly selected days - one weekday and one weekend day. Information was obtained using time diaries about what respondents did, where they were, who did the activities with them, who else was there, how they felt, and (for household and care-related activities) for whom the activity was performed. Detailed information was obtained about health, functioning, well-being, and stylized time use/participation measures. The inclusion of data from the main PSID allows for analyses about how time use varies, as a consequence of pre-existing health, disability, and economic status of the family, from both care givers' and care recipients' perspectives. Linkages to subsequent waves of PSID will allow analysis of the implications of time use for a variety of future health outcomes. Plans are underway to collect a second wave of DUST on all PSID individuals aged 60 and older in 2013.

\section{The Child Development Supplement (CDS) and the Transition into Adulthood (TA) study}

Beginning in 1997, the CDS collected information on up to two randomly-selected 0-12 year old children $(\mathrm{N}=3,563)$ and their caregivers in PSID families. The scientific aim was to provide researchers with a comprehensive, nationally representative (with child-based weights), prospective database of young children and their families, for studying the dynamic process of child development. The same children and their caregivers were re-interviewed in 2002/2003 and again in 2007/2008 with a child-based response rate exceeding $90 \%$ in the most recent wave. Topics included: health, skills assessments, parenting styles, time use, school resources and the learning environment in the home, and socio-emotional characteristics of children and their parents.
In 2005, in recognition that the years from 18-24 are critical for life span development, the PSID began a new study designed to follow the children from CDS who had turned age 18 and had completed or left high school and had families still active in PSID, called the Transition into Adulthood (TA) study. The primary scientific aim of TA is to understand the causes and consequences of social, economic, and health transitions of young adults. Information is collected about educational pursuits, employment, occupational choices, education and career expectations, family responsibilities, skills and abilities, intimate relationships, and more. Along with data collected during the CDS, detailed information is available about development from early and middle childhood through adolescence and into adulthood; additional information will be collected on this cohort over its life course as these youth transition to economic independence and become PSID Heads and Wives. TA data have been collected biennially for 2005-2011 and will be collected through 2015 at which time all children from CDS will have been observed at least once in the study. The response rate for TA was $92 \%$ in the most recent wave. The CDS-TAPSID archive is unique in the scientific research opportunities it presents for inter-generational and life course analysis. ${ }^{v}$

\section{Data distribution and documentation}

The majority of PSID data and documentation have been freely and publicly available on the Internet since 1996 through the PSID Data Center (www.PSID.org). Information is currently available on nearly 70,000 variables, on nearly 70,000 individuals, and for all waves of main PSID data and supplements. Users can create customized data extracts from any set of waves by searching or browsing for variables, obtain customized codebooks specific to their data extract, and can archive data extracts for shared and future use. Users "load" their data carts with variables by wave. Variable descriptions, including univariate statistics and names of the same variable in other waves, are viewed by clicking an "openbook" icon next to each variable. Users can edit their cart by removing or adding variables through a return to the "data aisle." Data carts may be saved, allowing specific extracts to be shared with colleagues, 
reviewers, and students. A range of file formats is available when the user is ready to "check out," including SAS, STATA, SPSS, dBase, Excel, and ASCII.

PSID developed an online cross-year variable index that facilitates searching and browsing all variables across the full archive from 1968 to the most recent wave, and for all waves of CDS and TA. Organized by content domains, the index is integrated with the Data Center so that users can view the codebook and add variables directly to their data cart from the index.

PSID has developed user tutorials covering a variety of topics. The most recent tutorial provides instruction on creating parent-adult child pairs to examine inter-generational transmission of wealth, health, and other outcomes. These tutorials have been positively received by the research community and by teachers (Stafford and Chiteji 2004).

Finally, an application is available called the Family Identification Mapping System (FIMS) that automatically creates a customized file containing identifiers for PSID respondents' relatives (including biological and adoptive children, parents, grandparents, great-grandparents, and siblings). FIMS greatly simplifies the process of creating genealogical samples by automatically generating a data extract based on user input.

\section{Ethical approval, funding, and administration}

The majority of PSID data and documentation are freely and publicly available on the Internet. Before downloading public data, users must register with the PSID and agree to conditions of use, which include pledging to make no attempt to identify study participants, and to report any identification of study participants or data errors immediately to PSID. Individuals wishing to obtain restricted data such as geospatial identifiers must provide a data security plan that meets PSID data safeguarding requirements, and have approval from their institution's human subjects review and/or privacy board (described here: http://simba.isr.umich.edu/restricted/RestrictedUse. aspx). The University of Michigan Health Sciences and Behavioral Sciences Institutional Review Board conducts annual reviews of the PSID data collection and distribution protocols and survey instruments to ensure the rights and welfare of its research participants are protected.

The National Science Foundation has been the lead funder of PSID over the past several decades. Recent support has also been received from the following organizations: National Institute on Aging, Eunice Kennedy Shriver National Institute on Child Health and Human Development, Economic Research Service of the U.S. Department of Agriculture, the Center on Philanthropy at Indiana University, the Assistant Secretary for Planning and Evaluation of the Department of Health and Human Services, and the Department of Housing and Urban Development. The study has been housed at the Institute for Social Research, University of Michigan, from its beginning in 1968 to the present and is directed by a team of social scientists. Since 1982, a Board of Overseers has fostered input from the national community of scholars, researchers, and policymakers.

\section{Research potential of the PSID for life course research}

The extended time series and consistently high response rates of the PSID provide substantial analytic power to study antecedents and consequences of a range of social, health, and economic factors. For older sample members in particular, the history available is extraordinarily rich. Since individuals are followed over the entire life course, the number of waves that an individual appears in the sample is related to their age. However, individuals who were born into PSID families also have substantial information on their childhood circumstances from their parents' and grandparents' reports. This combination of information on childhood circumstances and later adult behavior and outcomes represents a major analytical strength that supports a variety of different analyses. Moreover, the analytical samples are large. For instance, approximately 3,000 individuals in the original cohort under age 18 in 1968 were ages 50 or older by 2007 and are therefore represented in the data for a full 40 years of their lives. This cohort, born 1950-1968, overlaps substantially with the 1946-1964 Baby Boom generation and is now reaching the ages where life events such as acute health shocks, chronic disease, and labor force transitions occur. For 
children in the CDS and TA, a wealth of information exists on their behavior, health, and development as they passed through early, middle, and late childhood and into adolescence and young adulthood, and, increasingly, as members of the main PSID. The resulting data can be used to better understand how early circumstances, such as childhood socioeconomic status, health, neighborhood and school characteristics, and educational choices, shape health and well-being over the life course.

The following of sample members who are descendants of the original 1968 sample yields interand intra-generational samples, which are powerful additions to the study of life course development. The inter-generational sample is comprised of adult children who split off from their sample parents to form their own households and who are recruited into the study. Intra-generational analyses have focused on outcome comparisons among siblings, as a means to control for, or examine, unmeasured family effects (e.g. Conley and Glauber 2007). Relative-pairs that can be examined in the PSID include dyads formed from parents and children, from siblings, and from grandparents and grandchildren. There are hundreds, and in many cases thousands, of these pairs within the PSID; they are typically observed for many years, leading to a large number of relative-pair-year observations. In 2009 alone, PSID had 4,626 Heads/Wives who had a parent in the study, and 4,927 had a sibling in the study who was also a Head or Wife in that year (yielding about 2500 sibling pairs). Among Heads or Wives aged 50 and older in 2009, 2,858 had an adult child participate in the main intervew (many more had children interviewed in CDS-TA), 1,285 had at least one sibling interviewed, and 722 had a parent interviewed. For many PSID families, self-reported information is currently available on up to four generations within the same family, at various points in their life course.

\subsection{Illustrative research examples}

This section provides a small sampling of ways the data have been used for life course research, that may generate new ideas and future scientific discovery. The PSID website provides a complete bibliography of all studies using the data.
Effects of the Great Recession on young adults

PSID and TA data provide an unprecedented opportunity to examine how recent economic adversity starting at the end of 2007 in the U.S., in combination with secular changes in federal financial and mortgage policies, have shaped schooling and employment choices of young adults. Recent work has shown that changes in a household's housing wealth in the four years prior to a child being of college-age affects the likelihood that the child attends college (Lovenheim 2010). Data from the recent PSID foreclosure and mortgage distress module can be used to study how exposure to financial adversity defines early labor force participation and its link to later employment opportunities and educational trajectories over the life course. The choices and experiences in these cohorts can be compared with those of young adults who reached age 18 or 19 before the financial crisis.

\section{Marital transitions}

Studies using the PSID have examined trends in marriage, cohabitation, divorce, and separation, and the causes and consequences of marital transitions. Studies have found that factors influencing marital transitions include risk preferences (Schmidt 2008), education (Ono 2009), household bargaining (Cooke 2006), child support (Chiappori and Weiss 2007), and job loss (Charles and Stephens 2004). Studies have advanced scientific understanding of the impact of marriage, cohabitation, divorce, and separation on numerous outcomes, including labor supply (Aughinbaugh 2010), expenditure patterns (DeLeire and Kalil 2005), child development (Page and Stevens 2005; Bjorklund et al 2007), assets and debt among women (Fisher 2005), and bankruptcy filings (Fisher 2006). The data have been used to document the weakening over the past three decades of marriage and the nuclear family in the U.S. (Clark and Withers 2009; Seltzer et al 2005).

\section{Fertility and birth outcomes}

PSID is an important data source for understanding the causes and consequences of teen childbearing, with recent work (e.g. Sullivan et al 2010; Wolfe et al 2007; Lopoo 2005) building on numerous studies from the 1990s and early 2000s (Geronimus and Korenman 1992, 1993; Haveman et 
al 1997, 2001; Corcoran and Kunz 1997; Hoffman et al 1993; Foster et al 1998a, 1998b). Studies of the determinants of fertility among women of all ages have examined the effects of child support (Plotnick et al 2007), tax policy (Huang 2008), state-level welfare programs (Ryan at el 2006), and neighborhood poverty (South and Crowder 2010). The data have been used to examine the effects of birth outcomes and health in early childhood on health and well-being in later life (Johnson and Schoeni 2009; Haas 2007; Smith 2009).

\section{Effects of neighborhoods over time}

The availability across the life course of PSID individuals' census tract of residence (and census block beginning in 2009), through a restricted use contract, permits the study of neighborhood effects on development. A number of studies have used the data to examine neighborhood effects on child, adolescent, and young adult development (Dearing et al 2009; Jackson and Mare 2007; Timberlake 2009a, 2009b; Wimer et al 2008), health (Do and Finch 2008; Halliday 2007; Halliday and Kimmitt 2008; Johnson and Schoeni 2009), education (Brooks-Gunn et al 1993; Crowder and South 2003; Galster et al 2007; Harding 2003), income and earnings (Sharkey 2008), the inter-generational transmission of neighborhood context (Dawkins 2005a; Sharkey 2008; Solon et al 2000), and fertility behavior (Clark 2009; South and Crowder 2010; South 1999, 2001a, 2001b). Because of its oversample of African American families, the data have been used to examine levels and trends in racial equality in neighborhood economic status and migration (Sharkey 2008; Dawkins 2005b, 2006; Freeman 2005a, 2005b, 2008; South and Crowder, 2005; Timberlake 2007; White et al 2005; Vartanian et al 2007; Crowder and South 2005).

Socio-economic outcomes across and within generations of the same family

Because PSID follows adult children as they form their own households, it is uniquely positioned to investigate intergenerational effects. The data have been used to examine correlations across generations in health (Davis et al 2008; Valerio et al 2009), socioeconomic status (Charles and Hurst 2003; Eberharter 2008; Gouskova et al 2010; Lee and Solon 2009;
Mayer and Lopoo 2005; Solon 1992; Vartanian et al 2007), and philanthropic behavior (Wilhelm 2008). In fact, because of the length of the panel, PSID is now being used to estimate changes over time in the intergenerational transmission of economic status (Lee and Solon 2009; Mayer and Lopoo 2008). Researchers are also beginning to use the health data in conjunction with the socio-economic data to examine the extent to which transmission of health across generations within the same family accounts for the transmission of socio-economic status, and vice versa (Johnson and Schoeni 2009).

Life course consumption, savings, and wealth accumulation

The economic position of individuals nearing retirement is heavily influenced by saving and consumption decisions made during their working years. The experience of the large Baby Boom generation - the leading edge of which turns age 65 in 2011 -- is particularly well-represented in the PSID. Boomers were ages 4 to 22 years old when the PSID began in 1968, and most were still living in their parents' home. Substantial data collected on savings and wealth over several decades can be used to provide insights into how the financial behaviors and decision-making over the lifetimes of this generation has shaped their economic well-being as they reach retirement age.

\section{Comparative research over time and across countries}

The design of the PSID offers both flexibility to study emerging trends, and harmonization of key content to facilitate cross-national comparisons across all age groups. Comparable panels which facilitate study of the interplay of social and economic policies, health trajectories, and economic well-being over the life course (Banks et al 2003, 2009; Bjorkland et al 2007; Burkhauser et al 2005; Eberharter 2008) include the UK Understanding Society study, the German Socio-Economic Panel Study, the Household, Income and Labour Dynamics in Australia Survey, and many others. The Cross-National Equivalence File Project at Cornell University has further facilitated comparative analysis, by aligning variables between PSID and its companion surveys. 


\section{The Future of PSID}

As of this writing, data collection of the 2011 main interview has concluded and the data are being processed for release in 2012. Plans are underway to collect new information in 2013 that will respond to emerging research questions and policy issues. For example, in recognition of the role of the extended family as an increasingly important source of assistance over the life course (Bianchi et al 2008), PSID will provide a more complete enumeration of members of extended families and assess short-term transfers of time and money and long-term, life-cycle transfers for education and housing. Moreover, to enhance information available describing the earliest stage of life, additional data will be collected about between-wave births, and a protocol for obtaining links to birth records will be tested. An education update will be collected from all family members, yielding timely information about investments in education over the life course. In 2014, PSID plans to collect new data on psychological well-being, providing an unique opportunity to study influences of social and economic factors on well-being across all age groups. Finally, two high priorities in the next few years are the addition of a post-1997 immigrant sample refresher, and the implementation of a new PSID Child Development Supplement, in order to collect detailed information on the health, development, and well-being of all (nearly 7,000) children under age 18, including biomeasures such as DNA (Sastry et al 2009).

\section{Acknowledgements}

Support for this work was provided by the National Science Foundation (SES 0518943), the National Institute on Aging (P01-AG029409; R01-AG019802), and the Eunice Kennedy Shriver National Institute of Child Health and Human Development (R01HD052646; R01HD33474).

\section{References}

Andreski P, McGonagle KA and Schoeni RF. (2009) Analysis of the Quality of the Health Data in the Panel Study of Income Dynamics. Panel Study of Income Dynamics Technical Paper Series, \#09-02. Retrieved from: http://psidonline.isr.umich.edu/Publications/Papers/tsp/2009-02 Quality Health Data PSID .pdf

Aughinbaugh A. (2010) The effects of remarriage on women's labor supply. Journal of Population Economics, 23, 1151-1176. http://www.springerlink.com/content/nw314k136j5n8361/

Banks J, Blundell R and Smith JP. (2003) Financial wealth inequality in the United States and Great Britain. The Journal of Human Resources, 38, 241-279. http://www.ssc.wisc.edu/jhr/2003ab/banks.html

Banks J, Kapteyn A, Smith JP and van Soest A. (2009) Work disability is a pain in the ${ }^{* * * *}$, especially in England, the Netherlands, and the United States. In DM Cutler and DA Wise. eds. Health at Older Ages: The Causes and Consequences of Declining Disability. Pp 251-293.University of Chicago Press, Chicago, IL.

Bianchi SM, Hotz VJ, McGarry K and Seltzer JA. (2008) Intergenerational Ties: Theories, Trends, and Challenges. In A Booth, AC Crouter, SM Bianchi, and JA Seltzer. eds. Intergenerational Caregiving. Pp 3-43. Urban Institute Press, Washington DC.

Bosworth BB and Anders S. (2008) Savings and Wealth Accumulation in the PSID 1984-2005. Center for Retirement Research at Boston College Working Paper, 2008-2. Retrieved from: http://crr.bc.edu/images/stories/Working Papers/wp 20082.pdf?phpMyAdmin=43ac483c4de9t51d9eb41\&phpMyAdmin=1c3c4c81b524t7dd8ff77

Bjorklund A, Ginther DK and Sundstrom M. (2007) Family structure and the child outcomes in the USA and Sweden. Journal of Population Economics, 20, 183-201. $\mathrm{ftp}: / /$ repec.iza.org/RePEc/Discussionpaper/dp1259.pdf

Brooks-Gunn J, Duncan GJ, Klebanov PK and Sealand N. (1993) Do neighborhoods influence child and adolescent development? American Journal of Sociology, 99, 353-95. http://www.jstor.org/stable/2781682

Burkhauser RV, Giles P, Lillard DR and Schwarze J. (2005) Until death do us part: An analysis of the economic well-being of widows in four countries. The Journals of Gerontology Series B: Psychological Sciences and Social Sciences, 60, S238-S246.

Card D, Chetty R, Feldstein M and Saez E. (2010) Expanding access to administrative data for research in the United States. National Science Foundation white paper. 
Charles KK and Stephens M. (2004). Job displacement, disability, and divorce. Journal of Labor Economics, 22, 489-523. http://www.nber.org/papers/w8578

Charles KK and Hurst E. (2003) The correlation of wealth across generations. Journal of Political Economy, 111, 1155-1182. http://www.jstor.org/stable/3555236

Charles KK, Danziger S, Li G and Schoeni R. (2004). Comparison of estimates of spending in the PSID and CEX. Working Paper, University of Michigan, MI.

Chiappori PA and Weiss Y. (2007) Divorce, remarriage and child support. Journal of Labor Economics, 25, 37-74. http://www.jstor.org/stable/10.1086/508731

Clark WAV and Withers SD. (2009) Fertility, mobility and labour-force participation: A study of syncronicity. Population, Space and Place, 15, 305-321. http://onlinelibrary.wiley.com/doi/10.1002/psp.v15:4/issuetoc

Conley D and Glauber R. (2007) Family background, race, and labor market inequality. ANNALS of the American Academy of Political and Social Science, 609, 134-152. http://ann.sagepub.com/content/609/1/134.abstract

Cooke LP. (2006) Doing gender in context: household bargaining and risk of divorce in Germany and the United States. American Journal of Sociology, 112, 442-472. http://www.jstor.org/stable/10.1086/506417

Corcoran M and Kunz JP. (1997) Do Unmarried Births Among African-American Teens Lead to Adult Poverty? Social Service Review, 71, 274-287.

http://www.icpsr.umich.edu/icpsrweb/NACDA/biblio/resources/7176?journal=Social+Service+Review\& paging.startRow $=1 \&$ collection=DATA\&publicationYear $=1997$

Cornman JC, Freedman VA Stafford FP. (2011) Comparing Estimates of Time Use in the PSID's Supplement on Disability and Use of Time and the American Time Use Survey. Panel Study of Income Dynamics Technical Paper Series, \#11-01. Retrieved from: http://psidonline.isr.umich.edu/Publications/Papers/tsp/201101 Estimates\%20of\%20Time\%20Use DUST.pdf\#page=1

Couper MP and Nicholls, WL II. (1998) The history and development of computer assisted survey information collection. In MP Couper, RP Baker, J Bethlehem, CZF Clark, J Martin, WL Nicholls II, et al. eds. Computer assisted survey information collection. Pp. 1-21. John Wiley, New York. http://www.wiley.com/WileyCDA/WileyTitle/productCd-0471178489.html

Crowder KD and South SJ. (2003) Neighborhood distress and school dropout: The variable significance of community context. Social Science Research, 32, 659-698. http://www.sciencedirect.com/science/article/pii/S0049089X03000358

Crowder KD and South SJ. (2005) Race, class and changing patterns of migration between poor and nonpoor neighborhoods. American Journal of Sociology, 110, 1715-1763.

Curtin R, Presser S and Singer E. (2005) Changes in telephone survey nonresponse over the past quarter century. Public Opinion Quarterly, 69, 87-98. http://poq.oxfordjournals.org/content/69/1/87.abstract http://www.jstor.org/stable/10.1086/428686

Davis MM, McGonagle KA, Schoeni RF and Stafford FP. (2008) Grandparental and parental obesity influences on childhood overweight: Implications for primary care practice. Journal of American Board of Family Medicine, 21, 549-554. http://www.jabfm.org/content/21/6/549.short

Dawkins CJ. (2005a) Evidence on the Intergenerational Persistence of Residential Segregation by Race. Urban Studies, 42, 545-555. http://usj.sagepub.com/content/42/3/545.abstract

Dawkins CJ. (2005b) Racial gaps in the transition to first-time homeownership: the role of residential location. Journal of Urban Economics, 58, 537-554. http://www.mendeley.com/research/racial-gaps-transitionfirsttime-homeownership-role-residential-location-12/

Dawkins CJ. (2006) Are social networks the ties that bind families to neighborhoods? Housing Studies, 21, 867881. http://www.tandfonline.com/doi/abs/10.1080/02673030600917776

Dearing E, Wimer C, Simpkins SD, Lund T, Bouffard SM, Caronongan P, Kreider H and Weiss H. (2009) Do neighborhood and home contexts help explain why low-income children miss opportunities to participate in activities outside of school? Developmental Psychology, 45, 1545-1562. http://www.researchconnections.org/childcare/resources/17297?classifCode=6-16\&paging.startRow $=1 \&$ peerReview=yes

de Leeuw E and de Heer W. (2002) Trends in Household Survey Nonresponse: A Longitudinal and International Comparison. In RM Groves, DA Dillman, JL Eltinge and RJA Little. eds. Survey Nonresponse Pp. 41-54. Wiley, New York.

DeLeire T and Kalil A. (2005) How do cohabiting couples with children spend their money? The Journal of Marriage and the Family, 67, 286-295. http://onlinelibrary.wiley.com/doi/10.1111/j.0022$\underline{2445.2005 .00116 . x / a b s t r a c t}$ 
Do DP and Finch BK. (2008) The link between neighborhood poverty and health: context or composition? American Journal of Epidemiology, 168, 611-619. http://aje.oxfordjournals.org/content/168/6/611.short

Eberharter VV. (2008) Intergenerational income inequality and dynastic poverty persistence: Germany and the United States compared. Research on Economic Inequality, 16, 157-175. http://www.emeraldinsight.com/books.htm?chapterid=1775394

Fisher JD. (2005) The ability of women to repay debt after divorce. Journal of Women, Politics \& Policy, 27, 161168.

Fisher JD. (2006) Til debt do us part: a model of divorce and personal bankruptcy. Review of Economics of the Household, 4, 35-52. http://www.ingentaconnect.com/content/klu/reho/2006/00000004/00000001/00006696

Fitzgerald J. (2011) Attrition in models of intergenerational links in health and economic status in the PSID. Berkeley Electronic Journal of Economic Analysis \& Policy Vol. 11: Issue 3 (Advances), Article 2. http://www.bepress.com/cgi/viewcontent.cgi?article=2868\&context=bejeap

Fitzgerald J, Gottschalk P and Moffitt R. (1998) An analysis of sample attrition in panel data. The Journal of Human Resources, 33, 251-99. http://www.jstor.org/stable/146433

Foster EM and Furstenberg FF. (1998a) Most disadvantaged children: who are they and where do they live? Journal of Poverty, 2, 23-47. http://www.tandfonline.com/doi/abs/10.1300/J134v02n02 02

Foster EM, Jones D and Hoffman S. (1998b) The economic impact of nonmarital childbearing: how are older, single mothers faring? Journal of Marriage and the Family, 60, 163-174. http://www.jstor.org/stable/10.2307/353449

Freedman VA and Cornman J. (2011) The Panel Study of Income Dynamics' Disability and Use of Time Supplement: User's Guide. University of Michigan, MI. http://psidonline.isr.umich.edu/Guide/documents.aspx

Freeman L. (2005a) Black homeownership: the role of temporal changes and residential segregation at the end of the 20th century. Social Science Quarterly, 86, 403-426. http://onlinelibrary.wiley.com/doi/10.1111/j.0038-4941.2005.00310.x/full

Freeman L. (2005b) Displacement or succession? Residential mobility in gentrifying neighborhoods. Urban Affairs Review, 40, 463-491. http://uar.sagepub.com/content/40/4.toc

Freeman L. (2008) Is class becoming a more important determinant of neighborhood attainment for AfricanAmericans? Urban Affairs Review, 44, 3-26. http://uar.sagepub.com/content/44/1.toc

Galster G, Marcotte DE, Mandell M, Wolman H and Augustine N. (2007) The influence of neighborhood poverty during childhood on fertility, education and earnings outcomes. Housing Studies, 22, 723-751. http://home.gwu.edu/ nya/Galster etal 07.pdf

Geronimus AT and Korenman S. (1992) The socioeconomic consequences of teen childbearing reconsidered. The Quarterly Journal of Economics, 109, 1187-1214.

Geronimus AT and Korenman S. (1993). The socioeconomic costs of teenage childbearing: evidence and interpretation. Demography, 30, 281-290. http://qje.oxfordjournals.org/content/107/4/1187.short

Gouskova EP, Andreski P and Schoeni RF. (2010) Comparing estimates of family income in the Panel Study of Income Dynamics and the March Current Population Survey, 1968-2007. Panel Study of Income Dynamics Technical Paper Series, \#10-01. Retrieved from: http://psidonline.isr.umich.edu/Publications/Papers/tsp/2010-01 comparing estimates of fam.pdf

Gouskova E, Chiteji N and Stafford F. (2010) Estimating the intergenerational persistence of lifetime earnings with life course matching: evidence from the PSID. Labor Economics, 17, 592-597. http://www.sciencedirect.com/science/article/pii/S0927537109000499

Haas SA. (2007) The long-term effects of poor childhood health: an assessment and application of retrospective reports. Demography, 44, 113-135. http://mtw160150.ippl.jhu.edu/journals/demography/related/v044/44.1haas.html

Halliday TJ. (2007) Business cycles, migration and Health. Social Science and Medicine, 64, 1420-1424. http://www.sciencedirect.com/science/article/pii/S0277953606005880

Halliday TJ and Kimmitt M. (2008) Selective migration and health in the USA, 1984-93. Population Studies, 62, 321-334. http://ftp.iza.org/dp3458.pdf

Harding D. (2003) Counterfactual models of neighborhood effects: the effect of neighborhood poverty on high school dropout and teenage pregnancy. American Journal of Sociology, 109, 676-719. http://www.jstor.org/stable/3568577

Haveman R, Wolfe B and Peterson E. (1997) Children of early childbearers as young adults. In Kids Having Kids: Costs and Social Consequences of Teen Pregnancy. Pp 257-284.Urban Institute Press, Washington DC. 
Haveman R, Wolfe B and Pence K. (2001) Intergenerational effects of nonmarital and early childbearing. In LL Wu and B Wolfe. eds. Out of Wedlock: Causes and Consequences of Nonmarital Fertility, Pp 287-316. Russell Sage Foundation, New York.

Hill MS. (1992) The panel study of income dynamics: a user's guide. Sage Publications, Newbury Park, CA.

Hoffman S, Foster EM and Furstenberg FF. (1993) Reevaluating the costs of teenage childbearing. Demography, 30, 291-296. http://www.springerlink.com/content/e17684r567083k0w/

Huang JT. (2008) The personal tax exemption and married women's birth spacing in the United States. Public Finance Review, 36, 728-748.

Institute for Social Research. (2011) Panel Study of Income Dynamics main interview user manual, Release 2011.1. University of Michigan, MI. http://psidonline.isr.umich.edu/Guide/documents.aspx

Jackson MI and Mare RD. (2007) Cross-sectional and longitudinal measurements of neighborhood experience and their effects on children. Social Science Research, 36, 590-610.

http://www.mendeley.com/research/crosssectional-and-longitudinal-measurements-of-neighborhoodexperience-and-their-effects-on-children/

Johnson R and Schoeni RF. (2009) The influence of early-life events on human capital, health status, and labor market outcomes over the life course. Working paper. University of California, Berkeley, CA.

Killewald A, Andreski P and Schoeni RF. (2011) Trends in item nonresponse in the PSID, 1968 -2009. Panel Study of Income Dynamics Technical Series Paper \#11-02, Survey Research Center, University of Michigan, MI. http://psidonline.isr.umich.edu/Publications/Papers/tsp/201102 Killewald Andreski Schoeni.pdf\#page $=1$

Lee $\mathrm{Cl}$ and Solon G. (2009) Trends in intergenerational income mobility. Review of Economics and Statistics, 91, 766-772. http://www.mitpressjournals.org/toc/rest/91/4

Li G, Schoeni RF, Danziger S and Charles KK. (2010) New Expenditures in the PSID: Comparison with the CE. Monthly Labor Review. 133, 29-39.

Lopoo LM. (2005) Maternal employment and teenage childbearing: evidence from the PSID. Journal of Policy Analysis and Management, 24, 23-24.

Lovenheim MF. (2010) The effect of liquid housing wealth on college enrollment. Unpublished manuscript. Cornell University, Cornell University, Ithaca, NY.

Mayer SE and Lopoo LM. (2005) Has the Intergenerational Transmission of Economic Status Changed? Journal of Human Resources, 40, 169-185. http://ihr.uwpress.org/content/XL/1/169.abstract

Mayer SE and Lopoo LM. (2008) Government spending and intergenerational mobility. Journal of Public Economics, 92, 139-158. http://ideas.repec.org/a/eee/pubeco/v92y2008i1-2p139-158.html

McGonagle KA, Couper MP and Schoeni RF. (2011a) Keeping track of panel members: An experimental test of a between-wave contact strategy. Journal of Official Statistics, 27, 319-338. http://www.jos.nu/Articles/abstract.asp?article $=272319$

McGonagle KA, Schoeni RF, Couper MP and Mushtaq M. (2011b) An incentive experiment designed to increase response to a between-wave contact update mailing in two panel studies. Survey Practice, http://surveypractice.wordpress.com/2011/06/

McGonagle K, Couper M and Schoeni RF. (2009) An experimental test of a strategy to maintain contact with families between waves of a panel study. Survey Practice, http://surveypractice.wordpress.com/2009/06/29/panel-contacts/

Ono H. (2009) Husbands' and wives' education and divorce in the United States and Japan, 1946-2000. Journal of Family History, 34, 292-322.

http://jfh.sagepub.com/content/34/3/292.short?rss=1\&ssource=mfr\&patientinformlinks=yes\&legid=spifh;34/3/292

Page ME and Stevens $\mathrm{AH}$. (2005) Understanding racial differences in the economic costs of growing up in a single-parent family. Demography, 42, 75-90. http://muse.jhu.edu/journals/dem/summary/v042/42.1page.html

Plotnick RD, Garfinkel I, McLanahan S and Ku I. (2007) The impact on child support enforcement Policy on Nonmarital Childbearing. Journal of Policy Analysis and Management, 26, 79-98. http://ideas.repec.org/a/wly/ipamgt/v26y2007i1p79-98.html

Ryan S, Manlove J and Hofferth SL. (2006) State-level welfare policies and nonmarital subsequent childbearing. Population Research and Policy Review, 25, 103-126. http://www.springerlink.com/content/q3723417q4734720/?p=03c05ebe757c4295a5c7d38b709ff8c9\& $\mathrm{pi}=0$

Sastry N, McGonagle KA and Schoeni RF. (2009) Introduction to the Special Issue on the Scientific Assessment of Biomeasures in the Panel Study of Income Dynamics. Biodemography and Social Biology, 55, 113-117. http://www.tandfonline.com/toc/hsbi20/55/2 
Schmidt L. (2008) Risk preferences and the timing of marriage and childbearing. Demography, 45, 439-459. http://muse.jhu.edu/journals/demography/toc/dem.45.2.html

Schoeni RF, Stafford FP, McGonagle KA and Andreski P. (forthcoming). Response rates in national panel surveys. In D Massey and R Tourangeau. eds. The Future of Social Science Surveys: Opportunities and Challenge. Russell Sage Press, New York.

Seltzer JA, Bachrach CA, Bianchi SM, Bledsoe CH, Casper LM, Chase-Lansdale PL, DiPrete, TA, Hotz VJ, Morgan SP, Sanders SG and Thomas D. (2005) Explaining family change and variation: challenges for family demographers. Journal of Marriage and Family, 67, 908-925. http://onlinelibrary.wiley.com/doi/10.1111/i.1741-3737.2005.00183.x/abstract

Sharkey P. (2008) The intergenerational transmission of context. American Journal of Sociology, 113, 931-969. http://www.jstor.org/stable/10.1086/522804

Smith JP. (2009) Reconstructing childhood health histories*. Demography, 46, 387-404. http://muse.jhu.edu/journals/demography/toc/dem.46.2.html

Solon G. (1992) Intergenerational income mobility in the United States. The American Economic Review, 82, 393408. http://www.aeaweb.org/aer/contents/index.php

Solon G, Page ME and Duncan GJ. (2000) Correlations between neighboring children in their subsequent educational attainment. The Review of Economics and Statistics, 82, 383-392. http://www.mitpressjournals.org/toc/rest/82/3

South SJ. (1999) Historical changes and life course variation in the determinants of premarital childbearing. Journal of Marriage and the Family, 61, 752-763. http://www.jstor.org/stable/i215041

South SJ. (2001a) The variable effects of family background on the timing of first marriage: United States, 19691993. Social Science Research, 30, 606-626. http://www.sciencedirect.com/science/journal/0049089X/30

South SJ. (2001b) Time-dependent effects of wives' employment on marital dissolution. American Sociological Review, 66, 226-245. http://www.asanet.org/journals/asr/

South SJ and Crowder KD. (2005) Exiting and entering high-poverty neighborhoods: Latinos, Blacks and Anglos compared. Social Forces, 84, 873-900. http://sf.oxfordjournals.org/content/84/2.toc

South SJ and Crowder KD. (2010) Neighborhood poverty and nonmarital fertility: spatial and temporal dimensions. Journal of Marriage and the Family, 72, 89-104. http://onlinelibrary.wiley.com/doi/10.1111/iomf.2010.72.issue-1/issuetoc

Stafford FP and Chiteji NS. (2004) Panel study of income dynamics online: An instructional resource. Social Science Computer Review, 22, 457-468. http://ssc.sagepub.com/content/22/4.toc

South SJ and Crowder KD. (2010) Neighborhood poverty and nonmarital fertility: spatial and temporal dimensions. Journal of Marriage and the Family, 72, 89-104. http://onlinelibrary.wiley.com/doi/10.1111/jomf.2010.72.issue-1/issuetoc

Sullivan K, Clark J, Castrucci B, Samsel R, Ronseca V and Garcia I. (2010) Continuing Education Mitigates the Negative Consequences of Adolescent Childbearing. Maternal Child Health Journal. http://www.springer.com/public+health/journal/10995

Timberlake JM. (2007) Racial and ethnic inequality in the duration of children's exposure to neighborhood poverty and affluence. Social Problems, 54, 319-342. http://www.jstor.org/stable/10.1525/sp.2007.54.issue-3

Timberlake JM. (2009a) "Scratchin' and surviving" or "movin' on up?" Two sources of change in children's neighborhood SES. Population Research and Policy Review, 28, 195-219. http://www.springerlink.com/content/0167-5923/27/2/

Timberlake JM. (2009b) Effects of household and neighborhood characteristics on children's exposure to neighborhood poverty and affluence. Social Science Research, 38, 458-476. http://www.journals.elsevier.com/social-science-research/

Valerio MA, Andreski PM, Schoeni RF and McGonagle KA. (2010) Examining the association between childhood asthma and parent and grandparent asthma status: implications for practice. Clinical Pediatrics, 49, 535541.

http://cpj.sagepub.com/search/results?fulltext=examining+the+association+between+childhood\&x=0\& $\mathrm{y}=0$ \&submit=yes\&journal $\mathrm{set}=\mathrm{spcpj \& src=selected \& andorexactfulltext=and}$

Vartanian TP, Buck PW and Gleason P. (2007) Intergenerational neighborhood-type mobility: examining differences between Blacks and Whites. Housing Studies, 22, 833-856. http://www.tandf.co.uk/journals/titles/02673037.asp

White KJC, Crowder KD, Tolnay SE and Adelman RM. (2005) Race, gender, and marriage: destination selection during the great migration. Demography, 42, 215-241. http://muse.jhu.edu/journals/demography/toc/dem42.2.html 
Wilhelm MO, Brown E, Rooney, PM and Steinberg R. (2008) The Intergenerational Transmission of Generosity. Journal of Public Economics, 92, 2146-2156. http://www.journals.elsevier.com/journal-of-publiceconomics/

Wimer C, Simpkins SD, Dearing E, Bouffard SM, Caronongan P and Weiss HB. (2008) Predicting youth out-ofschool time participation: multiple risks and developmental differences. Merrill-Palmer Quarterly: Journal of Developmental Psychology, 54, 179-207. http://www.apa.org/pubs/journals/dev/index.aspx

Wolfe B, Haveman R, Pence K and Schwabish JA. (2007) Do youth nonmarital childbearing choices reflect income and relationship expectations? Journal of Population Economics, 20, 73-100. http://www.popecon.org/searchthedatabase.php

\section{Endnotes}

' Detailed information about the study design, following rules, and wave-specific information may be found in the PSID Main Interview User Manual on the PSID website:

http://psidonline.isr.umich.edu/data/Documentation/UserGuide2009.pdf.

ii See Table 2 of the PSID User Manual for the number of original sample members who have been interviewed in each wave and Table 3 which lists the number of sample members in each wave who have left the study, died, or were dropped from the sample: http://psidonline.isr.umich.edu/data/Documentation/UserGuide2009.pdf.

iii See the PSID Technical Series Paper here for details on the immigrant sample addition

http://psidonline.isr.umich.edu/Publications/Papers/tsp/2000-04_Imm_Sample_Addition.pdf

${ }^{\text {iv }}$ Starting with the 2007 wave, three levels of PSID geospatial data are available, in order of descending precision: Census Tract, Block Group, and Census Block. Census Block is the smallest level of data made available by PSID. Several Blocks make up Block Groups, which in turn make up Census Tracts.

${ }^{v}$ For more information see the CDS and TA User Guides here: http://psidonline.isr.umich.edu/Guide/documents.aspx 